\title{
Impact of Native Grasses and Cheatgrass (Bromus tectorum) on Great Basin Forb Seedling Growth
}

\author{
Hilary Parkinson, ${ }^{1}$ Cathy Zabinski, ${ }^{2}$ and Nancy Shaw ${ }^{3}$
}

Authors are ${ }^{1}$ Research Associate and ${ }^{2}$ Associate Professor, Department of Land Resources and Environmental Sciences, Montana State University, Bozeman, MT 59717 USA; and ${ }^{3}$ Research Botanist, USDA Forest Service Rocky Mountain Research Station, Boise, ID 83706, USA.

\begin{abstract}
Re-establishing native communities that resist exotic weed invasion and provide diverse habitat for wildlife are high priorities for restoration in sagebrush ecosystems. Native forbs are an important component of healthy rangelands in this system, but they are rarely included in seedings. Understanding competitive interactions between forb and grass seedlings is required to devise seeding strategies that can enhance establishment of diverse native species assemblages in degraded sagebrush communities. We conducted a greenhouse experiment to examine seedling biomass and relative growth rate of common native forb species when grown alone or in the presence of a native bunchgrass or an exotic annual grass. Forb species included bigseed biscuitroot (Lomatium macrocarpum [Nutt. ex Torr. \& A. Gray] J.M. Coult. \& Rose), sulphur-flower buckwheat (Eriogonum umbellatum Torr.), hoary aster (Machaeranthera canescens [Pursh] Gray), royal penstemon (Penstemon speciosus Douglas ex Lindl.), and Munro's globemallow (Sphaeralcea munroana [Douglas ex Lindl.] Spach ex Gray); and neighboring grass species included bottlebrush squirreltail (Elymus elymoides [Raf.] Swezey), Sandberg bluegrass (Poa secunda J. Presl); and cheatgrass (Bromus tectorum L.). Forbs and grasses were harvested after 6, 9, or 12 wk of growth for biomass determination and calculation of relative growth rates (RGR) of forbs. Neither bunchgrass reduced biomass of any forb. RGR was reduced for royal penstemon when grown with either native grass and for Munro's globemallow when grown with bottlebrush squirreltail. Although only assessed qualitatively, forbs with vertically oriented root morphologies exhibited no reduction in RGR when grown with native grasses, compared to forbs with dense lateral branching, similar to the root morphology of native grasses. Biomass of forbs was reduced by $50 \%$ to $91 \%$ and RGR by $37 \%$ to $80 \%$ when grown with cheatgrass. Understanding native forb interactions with native grasses and cheatgrass will aid land managers in selecting effective seed mixes and making better use of costly seed.
\end{abstract}

Key Words: invasive species, relative growth rate, restoration, revegetation, root morphology

\section{INTRODUCTION}

Historically, plant species selected to restore burned or degraded plant communities in the Great Basin have been primarily grasses and shrubs (Plummer et al. 1968; DePuit 1986). Although native forbs have a number of important ecological roles, they have been traditionally overlooked in revegetation plans because of our lack of understanding of their establishment and resource requirements and the limited availability of seeds (Shaw et al. 2005; Walker and Shaw 2005). Recent efforts to address seed availability and methods to enhance establishment (Shaw et al. 2005) are based on the recognition that grasses, shrubs, and forbs are all necessary to restore community structure and function and conserve biodiversity. They are also essential to meet the habitat needs of numerous organisms (Kufeld 1973; Gregg et al. 2008; Davies and Bates 2010). Pronghorn antelope (Antilocapra americana Ord), for example, forage primarily on grasses in

\footnotetext{
Research was funded in part by the USDA Forest Service Rocky Mountain Research Station, Great Basin Native Plant Selection and Increase Project, and the US Dept of the Interior-Bureau of Land Management Great Basin Restoration Initiative.

At the time of research, Hilary Parkinson was a graduate student, Dept of Land Resources and Environmental Sciences, Montana State University, Bozeman, MT 59717, USA

Correspondence: Cathy Zabinski, Dept of Land Resources and Environmental Sciences, Montana State University, P0 Box 173120, Bozeman, MT 59717, USA. Email: cathyz@montana.edu
}

Manuscript received 17 February 2011; manuscript accepted 5 August 2012.

(c) 2013 The Society for Range Management spring and fall, and shrubs during the winter, but in summer months forbs may comprise up to $90 \%$ of their diet (Beale and Smith 1970). Along with shrubs, forbs are critical to maintaining pollinator populations (Gathmann and Tscharntke 2002). In healthy sagebrush (Artemisia spp.) plant communities, forbs and insects that depend on forbs provide the majority of the diet of sage-grouse (Centrocercus urophasianus Bonaparte) in spring and early summer (Drut et al. 1994; Gregg et al. 2008).

Because literature and practical experience pertaining to native forbs is scant, additional information on species phenology, relative growth rate (RGR), and root morphology can improve our understanding of species resource use in time and space. This will aid in selecting species and designing revegetation strategies to enhance partitioning of resources, thereby reducing competitive interactions among seeded species and increasing species richness of the established community (Pyke and Archer 1991; Schwinning and Ehleringer 2001).

A major challenge in revegetating disturbed sites in the Great Basin is competition with cheatgrass (Bromus tectorum L.), which is present on more than 40 million hectares in this region (Young and Evans 1978; Knapp 1996). Limiting competition among seeded species and rapidly establishing vegetative cover is especially important given the risk of cheatgrass invasion and subsequent dominance (Mack and Pyke 1983). The competitive attributes of this winter annual are well documented. It uses more water earlier in the growing season than many native plants by initiating root and shoot growth at lower temperatures (Arredondo et al. 1998), and exhibits greater root and 
shoot relative growth rates (Cline et al. 1977; Aguirre and Johnson 1991). Mature perennial plants are more resistant to competition from annual grasses (Humphrey and Schupp 2004), and some communities, especially those with a perennial grass component, can suppress cheatgrass growth or even reduce its density (Booth et al. 2003; Beckstead and Augspurger 2004; Getz and Baker 2008; Leger 2008). In disturbance scenarios, however, the seedling stage of native species is vulnerable to competition from cheatgrass (Aguirre and Johnson 1991; Humphrey and Schupp 2004; Yelenik and Levine 2010). Cheatgrass densities as low as 10 plants $\mathrm{m}^{-2}$ in the first year following fire can increase to 10000 plants $\mathrm{m}^{-2}$ within 3 yr (Young and Evans 1978), demonstrating that the window for seeded species to establish and persist can be quite narrow.

Constructing postdisturbance plant communities to maximize native species habitat and minimize exotic species invasion requires a strategy that uses highly competitive native species, but also accounts for establishment of a diverse mixture of species. Native grasses in sagebrush-steppe communities can increase resistance to invasion by nonnative species (Booth et al. 2003; Beckstead and Augspurger 2004; Chambers et al. 2007; Getz and Baker 2008; James et al. 2008), but those same grasses may either compete with or facilitate the recruitment of other species (Kindscher and Fraser 2000; Brown and Bugg 2001; Booth et al. 2003, Dickson and Busby 2009). Mature bottlebrush squirreltail plants (Elymus elymoides [Raf.] Swezey), for example, have a positive influence on diversity by increasing recruitment of sagebrush (Artemisia tridentata) seedlings and maintaining cheatgrass-free zones (Booth et al. 2003). However, grasses also reduce survival of forbs in restoration plantings (Kindscher and Fraser 2000; Brown and Bugg 2001; Dickson and Busby 2009), and therefore recommended protocols for revegetation strategies include 1) seeding forbs separately from grasses, 2) increasing forb seeding rates, or 3) reducing grass seeding rates to increase forb recruitment (Kindscher and Fraser 2000; Elstein 2004; Dickson and Busby 2009).

Because native forbs can improve community diversity and habitat values, a greater understanding of forb physiology and native grass effects on forb growth may provide useful information to reduce negative interactions among seeded species. In this study we examined the RGR of native forb species when grown with native perennial grasses or cheatgrass to assess their competitive abilities. Identifying forbs that maintain RGR in the presence of native grass seedlings will improve selection of effective native forb and grass restoration mixtures and seeding strategies for increasing establishment. Species that grow quickly at the seedling stage can reduce site availability for cheatgrass invasion, whereas slow-growing species may allow for a greater diversity of native forb establishment. Seed mixes therefore could be constructed with information on expected cheatgrass densities based on site history prior to the disturbance, burn intensity, and visual inspection (Young et al. 1976). Species identified as more vulnerable could be used in sites with little to no expected cheatgrass presence, whereas those species more resistant to cheatgrass competition could be seeded in sites with low to moderate background levels of cheatgrass. This will reduce the use of species at some sites that are not competitive with cheatgrass, preventing the waste of valuable forb seed.

In this study, we compared total biomass after 12 wk of growth, relative growth rates, and root mass ratios (RMR) and qualitative root morphology for five native Great Basin forb species under consideration as restoration species. Forb seedlings were grown either alone or with one of two native grasses to determine whether native grasses would facilitate or inhibit growth of each forb. Finally, native forbs were grown with cheatgrass, to determine whether they differed in their competitive response to this exotic grass. Competitive response is defined here as the "ability of an organism to avoid being suppressed by their companions," or have no to little reduction in growth with a neighbor compared to growth alone (Goldberg and Landa 1991). Given the lack of information on forb growth and forb response to grasses, we analyzed forb response to grasses, not grass response to forbs.

\section{METHODS}

\section{Plant Materials}

Perennial native forbs species used in our experiments included sulphur-flower buckwheat (Eriogonum umbellatum Torr.), bigseed biscuitroot (Lomatium macrocarpum [Nutt. ex Torr. \& A. Gray] J.M. Coult. \& Rose), hoary aster (Machaeranthera canescens [Pursh] Gray), royal penstemon (Penstemon speciosus Douglas ex Lindl.), and Munro's globemallow (Sphaeralcea munroana [Dougl. ex Lindl.] Spach ex Gray). All are insect pollinated. Seeds of the native grasses bottlebrush squirreltail and Sandberg bluegrass (Poa secunda J. Presl) were collected from plants growing at the Saylor Creek Range of southern Idaho, and seeds of the exotic annual cheatgrass were collected in the foothills around Boise, Idaho. Forb seed was collected in 2005 from the Snake River Plain of southern Idaho, at elevations less than 1524 m, except for Munro's globemallow, which was collected in Uintah Co., Utah at $1553 \mathrm{~m}$ (Table 1).

\section{Experimental Design}

Forb seed was stratified at $4.4^{\circ} \mathrm{C}$ for $2-12$ wk in JanuaryMarch 2007 (Parkinson 2008). In mid-March 2007, forb and grass seeds were transferred to Petri dishes lined with two layers of moistened Whatman no. 1 filter paper, sealed with Parafilm, and placed in a growth chamber set at a constant $24^{\circ} \mathrm{C}$, with $14 \mathrm{~h}$ light and $10 \mathrm{~h}$ dark. Germinating seeds were planted in 16-cm-diameter $\times 45$-cm-deep containers (Stuewe and Sons TP616) in growing media comprised of silt loam topsoil from Gallatin County, Montana, washed concrete sand, and peat moss $(1: 1: 1, \mathrm{v} / \mathrm{v} / \mathrm{v})$. Forbs were grown alone or with one of the following grass neighbors: cheatgrass, bottlebrush squirreltail, or Sandberg bluegrass. Two to three germinants per species were planted to account for mortality, and seedlings were thinned to a single forb or a single forb and grass after 10 $\mathrm{d}$ of growth.

Containers were placed on benches in a Montana State University greenhouse in a completely randomized experimental design. With five forb species, four neighbor treatments, and 18 replicates there were 360 total sampling units. Greenhouse temperatures were between $18^{\circ} \mathrm{C}$ and $24^{\circ} \mathrm{C}$ and photoperiod, as 
Table 1. Plant materials, seed characteristics, and location of seed collection sites.

\begin{tabular}{|c|c|c|c|c|}
\hline Common name & Scientific name & Plant family & Seed $\cdot g^{-1}$ & Collection site location and elevation ${ }^{1}$ \\
\hline Bigseed biscuitroot & Lomatium macrocarpum & Apiaceae & 99 & lat $43^{\circ} 30^{\prime} 48^{\prime \prime} \mathrm{N}$, long $116^{\circ} 7^{\prime} 55^{\prime \prime} \mathrm{W} ; 946 \mathrm{~m}$ \\
\hline Hoary aster & Machaeranthera canescens & Asteraceae & 1818 & lat $43^{\circ} 13^{\prime} 60^{\prime \prime} \mathrm{N}$, long $115^{\circ} 54^{\prime} 53^{\prime \prime} \mathrm{W} ; 958 \mathrm{~m}$ \\
\hline Munro's globemallow & Sphaeralcea munroana & Malvaceae & 300 & Uintah Co. Utah $<1524 \mathrm{~m}$ \\
\hline Royal penstemon & Penstemon speciosus & Scrophulariaceae & 687 & lat $43^{\circ} 23^{\prime} 13^{\prime \prime} \mathrm{N}$, long $116^{\circ} 01^{\prime} 13^{\prime \prime} \mathrm{W} ; 1013 \mathrm{~m}$ \\
\hline Sulphur-flower buckwheat & Eriogonum umbellatum & Polygonaceae & 328 & lat $43^{\circ} 28^{\prime} 06^{\prime \prime} \mathrm{N}$, long $116^{\circ} 05^{\prime} 22^{\prime \prime} \mathrm{W} ; 1032 \mathrm{~m}$ \\
\hline
\end{tabular}

${ }^{1}$ All forbs collected in Snake River Plain of southern Idaho except Munro's globemallow.

controlled with supplemental lights, provided $14 \mathrm{~h} \cdot \mathrm{d}^{-1}$ of light. Plants were watered daily for the first $14 \mathrm{~d}$, and every 2-3 d thereafter. After 6, 9, and $12 \mathrm{wk}$ of growth, six containers of each treatment were destructively harvested to obtain root and shoot biomass. Containers were turned on their sides and root material was slid out carefully so as not to disturb or tear roots and to observe root orientation. Forb and grass root material were carefully separated by hand, cleaned, and dried at $65^{\circ} \mathrm{C}$ for $48 \mathrm{~h}$, then weighed.

\section{Data Analysis}

Biomass differences among forb species after 6, 9, and $12 \mathrm{wk}$ of growth were analyzed with one-way analysis of variance (ANOVA) on log-transformed total biomass (SPSS 2006), with Tukey multiple-comparison tests for the 6-wk data, and Games-Howell post hoc tests for 9- and 12-wk data, because these data failed Levene's test for homogeneity of variance (Leech et al. 2004). RMR is root mass divided by total (root plus shoot) biomass. Differences between species in RMRs after 6, 9, and 12 wk were tested with one-way ANOVAs for data from each harvest with Tukey multiple-comparison tests $(\alpha=0.05)$.

Differences in instantaneous RGR were analyzed for all forbs except bigseed biscuitroot, which began to senesce in the greenhouse between Weeks 9 and 12. Instantaneous RGR was computed as the slope of the natural $\log$ of forb biomass regressed on weeks of growth. For each species, plants were ranked by total biomass at each harvest (from one to six) and paired with plants of equivalent rank from the 9- and 12-wk harvests to obtain six values for the RGR of each forb based on the three harvests. Ranking and pairing creates six RGR values (or slopes), allowing an assessment of variance within and among treatments as opposed to averaging the natural log of the six replicates from each harvest and using that to create one value for RGR. Differences among forb instantaneous RGRs were computed with the use of the Tukey multiple comparison test $(\alpha=0.05)$. Along with total RGR, the shoot and root RGR were computed separately. Additionally, to avoid the bias associated with pairing plants of similar size rank across harvest periods (Poorter 1989), differences in RGR among species were tested with the use of an ANCOVA of logtransformed biomass with harvest week as the covariate (SPSS 2006). The same RGR values (or slopes) were obtained as using the method above (ranking and pairing). Significant differences in RGR were identified by testing for an interaction between species and harvest week (time), which would indicate that at least one of the species differed in RGR (Poorter and Lewis 1986).
The effect of a grass neighbor on total biomass, total RGR, and shoot and root tissue RGR of each forb was tested with the use of one-way ANOVAs among neighbor treatments (alone, with cheatgrass, bottlebrush squirreltail, or Sandberg bluegrass). An ANOVA of RGR among neighbor treatments was not conducted for bigseed biscuitroot. The Tukey multiple comparison test $(\alpha=0.05)$ was used to determine which treatments differed.

\section{RESULTS}

\section{Forb Biomass and Root Growth Without Grass Neighbors}

Forbs exhibited large differences in total biomass after only 6 wk of growth (Table 2). Munro's globemallow was consistently the largest. By Week 12 its biomass was 7 and 16 times greater than the biomass of the next largest forbs, hoary aster and royal penstemon, respectively. Sulphur-flower buckwheat was intermediate and not significantly different from bigseed biscuitroot or royal penstemon at Weeks 6 and 9 , but by Week 12 its biomass was five times larger than bigseed biscuitroot, but only one-third the size of royal penstemon.

Differences in RMR among species were apparent after $6 \mathrm{wk}$ of growth and continued through Weeks 9 and 12 (Table 3). The RMR of bigseed biscuitroot exceeded that of the other species by an average of 4.2 times after 6 wk and by 1.7 to 3.6 times after $12 \mathrm{wk}$, respectively. Royal penstemon RMR was similar to that of Munro's globemallow, sulphur-flower buckwheat, and hoary aster after 6 wk of growth, but by Week 12 its RMR was 1.7 to 2 times that of the other three species, which exhibited similar RMRs throughout the 12-wk period.

Table 2. Total biomass (mean $\pm 1 \mathrm{SE}$ ) of forbs when growing alone after 6,9 , or 12 wk of growth. $F$ and $P$ values are from a one-way ANOVA of the log normal of total forb biomass of each species on each harvest date; $\mathrm{df}=$ 4,25 . Letters indicate significant differences at each harvest week (within a column) based on Tukey's multiple-comparison test $(P<0.05)$.

\begin{tabular}{lccc}
\hline & \multicolumn{3}{c}{ Total biomass $(\mathrm{g})$} \\
\cline { 2 - 4 } \multicolumn{1}{c}{ Common name } & \multicolumn{1}{c}{$6 \mathrm{wk}$} & \multicolumn{1}{c}{$9 \mathrm{wk}$} & $12 \mathrm{wk}$ \\
\hline Bigseed biscuitroot & $0.022 \pm 0.006 \mathrm{a}$ & $0.07 \pm 0.003 \mathrm{a}$ & $0.08 \pm 0.003 \mathrm{a}$ \\
Sulphur-flower buckwheat & $0.038 \pm 0.006 \mathrm{ab}$ & $0.16 \pm 0.04 \mathrm{ab}$ & $0.46 \pm 0.12 \mathrm{~b}$ \\
Royal penstemon & $0.067 \pm 0.004 \mathrm{~b}$ & $0.42 \pm 0.10 \mathrm{~b}$ & $1.50 \pm 0.33 \mathrm{c}$ \\
Hoary aster & $0.395 \pm 0.120 \mathrm{c}$ & $1.10 \pm 0.09 \mathrm{C}$ & $3.38 \pm 0.50 \mathrm{~d}$ \\
Munro's globemallow & $1.987 \pm 0.350 \mathrm{~d}$ & $8.75 \pm 0.92 \mathrm{~d}$ & $24.09 \pm 2.02 \mathrm{e}$ \\
$\quad F$ value & 72.4 & 139.40 & 145.62 \\
\hline
\end{tabular}


Table 3. Root-mass ratios (mean $\pm 1 \mathrm{SE}$ ) of forbs when growing alone after 6,9 , or 12 wk of growth. $F$ and $P$ values are from a one-way ANOVA among species on the log normal of root-mass ratio at each harvest, $\mathrm{df}=$ 4,25 . Letters indicate significant differences at each harvest week (within a column) based on the Tukey multiple-comparison test $(P<0.05)$.

\begin{tabular}{lccc}
\hline \multicolumn{1}{c}{ Common name } & 6 wk & 9 wk & 12 wk \\
\hline Bigseed biscuitroot & $0.60 \pm 0.06 \mathrm{a}$ & $0.75 \pm 0.01 \mathrm{a}$ & $0.83 \pm 0.01 \mathrm{a}$ \\
Royal penstemon & $0.13 \pm 0.02 \mathrm{~b}$ & $0.25 \pm 0.03 \mathrm{~b}$ & $0.48 \pm 0.02 \mathrm{~b}$ \\
Hoary aster & $0.17 \pm 0.02 \mathrm{~b}$ & $0.23 \pm 0.02 \mathrm{bc}$ & $0.29 \pm 0.01 \mathrm{c}$ \\
Sulphur-flower buckwheat & $0.15 \pm 0.02 \mathrm{~b}$ & $0.17 \pm 0.02 \mathrm{~cd}$ & $0.23 \pm 0.02 \mathrm{c}$ \\
Munro's globemallow & $0.13 \pm 0.01 \mathrm{~b}$ & $0.13 \pm 0.01 \mathrm{~d}$ & $0.24 \pm 0.02 \mathrm{c}$ \\
$\quad$ F value & 46.4 & 174.15 & 198.16 \\
\hline
\end{tabular}

Root morphology varied considerably among species. Bigseed biscuitroot was tap-rooted, with no lateral branches developing from the main root after 12 wk of growth (Fig. 1). In the first $6 \mathrm{wk}$, hoary aster was also tap-rooted, and developed lateral roots only between Weeks 9 and 12. Roots of sulphur-flower buckwheat were not tap-rooted; instead, all roots were extremely fine $(<1 \mathrm{~mm}$ diameter $)$, with minimal branching, only two or three lateral branches within $3-5 \mathrm{~cm}$ of the soil surface, which were oriented vertically. In contrast, roots of royal penstemon and Munro's globemallow were densely branched, distributed laterally as much as vertically, and had considerable branching near the soil surface and throughout the depth of the container.

\section{Forb Relative Growth Rates Without Grass Neighbors}

Because bigseed biscuitroot grew very little between Weeks 9 and 12 , consistent with the growth patterns of Great Basin Lomatium spp. in the field (H. Parkinson, personal observation, spring 2005-2007 field seasons), RGR was only calculated for the other forb species. The slopes of the natural $\log$ of total forb biomass by harvest time differed between species $\left(F_{3,20}=3.34 ; P<0.05\right)$. The slope of royal penstemon was greater than that of hoary aster, and slopes for sulphurflower buckwheat and Munro's globemallow were intermediate and not different than either royal penstemon or hoary aster (Fig. 2). Separating plant growth rates by root and shoot tissue

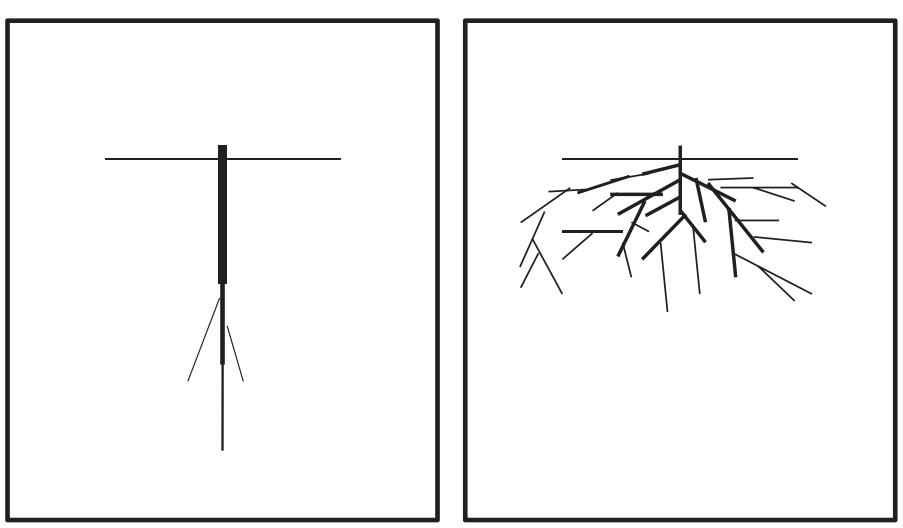

Figure 1. Diagram of forb root morphology types: A, Vertically oriented root morphology of bigseed biscuitroot, hoary aster, and sulphur-flower buckwheat. B, Dense lateral branching of Munro's globemallow and royal penstemon.

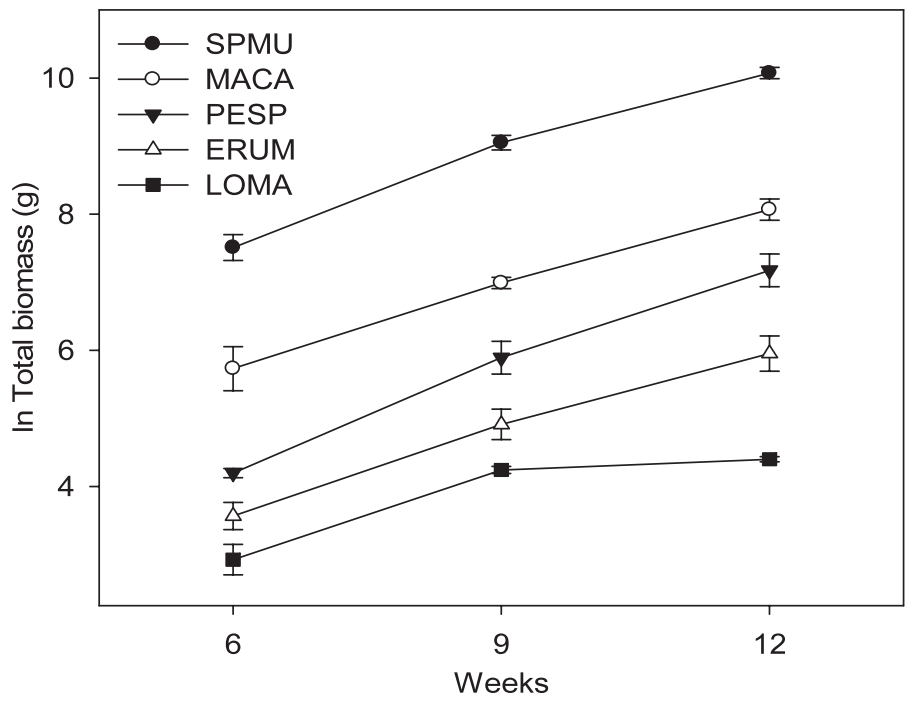

Figure 2. Natural log of total forb biomass ( $\pm 1 \mathrm{SE}$ ) when growing alone in a greenhouse for 6-12 wk. SPMU=Munro's globemallow; MACA=hoary aster; $\mathrm{PESP}=$ royal penstemon; $\mathrm{ERUM}=$ sulphur-flower buckwheat.

revealed that RGR of shoot tissue did not differ between species $\left(F_{3,20}=0.60\right)$; however, the RGR of root tissue varied among species $\left(F_{3,20}=11.42, P<0.0001\right)$. The RGR of royal penstemon root tissue $(0.72 \pm 0.06)$ was significantly greater than that of Munro's globemallow $(0.53 \pm 0.06)$, sulphur-flower buckwheat $(0.48 \pm 0.08)$, and hoary aster $(0.48 \pm 0.10)$; the latter three forbs were not different from each other.

\section{Forb Growth With Grass Neighbors}

Total grass biomass averaged across all forb neighbors was $1.8 \pm 0.22 \mathrm{~g}$ for Sandberg bluegrass, $7.3 \pm 0.54 \mathrm{~g}$ for bottlebrush squirreltail, and $24.0 \pm 0.52 \mathrm{~g}$ for cheatgrass. After 12 wk of growth, total biomass of all forbs when growing with a native grass was not different from growing alone (Table 4). In contrast, the total biomass of all forbs was reduced when growing with cheatgrass relative to growing alone. Compared to growth alone, reductions in forb biomass ranged from $50 \%$ for bigseed biscuitroot to $91 \%$ for royal penstemon.

Although a native grass neighbor did not affect forb biomass, values for total RGR were reduced when growing with a neighbor versus growing alone (Parkinson 2008). Both native grasses reduced the total RGR of royal penstemon by $25 \%$; bottlebrush squirreltail reduced the total RGR of Munro's globemallow by $18 \%$ (data not shown). Cheatgrass reduced the total RGR of all forbs, with the reductions ranging from $37 \%$ for Munro's globemallow to $80 \%$ for royal penstemon.

Sandberg bluegrass and bottlebrush squirreltail reduced the root RGR of royal penstemon by an average of $20 \%$ compared to growth alone (Fig. 3). Native grass neighbors did not impact root growth rate of sulphur-flower buckwheat, hoary aster, or Munro's globemallow. Cheatgrass reduced the root RGR of sulphur-flower buckwheat by $42 \%$ and royal penstemon by $74 \%$ (Fig. 3), but did not affect RGR of hoary aster or Munro's globemallow. Shoot RGR (Fig. 3) was not impacted by Sandberg bluegrass; however, bottlebrush squirreltail reduced shoot RGR of royal penstemon by 35\% and Munro's globemallow by $20 \%$, but did not affect shoot RGR of hoary aster or 
Table 4. Total forb biomass (mean $\pm 1 \mathrm{SE}$ ) among neighbor treatments after 12 wk of growth. $F$ and $P$ values are from one-way ANOVAs comparing forb biomass among neighbor treatments, $\mathrm{df}=3,20$. Letters indicate significant differences within a column $(P<0.05)$ based on Tukey multiple-comparison tests. Nontransformed data are presented; log-transformed data were used for analysis.

\begin{tabular}{lccccc}
\hline & \multicolumn{4}{c}{ Forb species } \\
\cline { 2 - 6 } Neighbor treatment & Bigseed biscuitroot & Sulphur-flower buckwheat & Royal penstemon & Hoary aster & Munro's globemallow \\
\hline Alone & $0.08 \pm 0.003 \mathrm{a}$ & $0.46 \pm 0.12 \mathrm{a}$ & $1.49 \pm 0.33 \mathrm{a}$ & $3.38 \pm 0.50 \mathrm{a}$ & $24.09 \pm 2.02 \mathrm{a}$ \\
Sandberg bluegrass & $0.06 \pm 0.01 \mathrm{ab}$ & $0.51 \pm 0.09 \mathrm{a}$ & $0.70 \pm 0.08 \mathrm{ab}$ & $5.30 \pm 1.26 \mathrm{a}$ & $22.13 \pm 2.38 \mathrm{a}$ \\
Bottlebrush squirreltail & $0.05 \pm 0.01 \mathrm{ab}$ & $0.29 \pm 0.11 \mathrm{ab}$ & $0.78 \pm 0.23 \mathrm{ab}$ & $5.50 \pm 0.40 \mathrm{a}$ & $23.77 \pm 2.51 \mathrm{a}$ \\
Cheatgrass & $0.04 \pm 0.01 \mathrm{~b}$ & $0.10 \pm 0.02 \mathrm{~b}$ & $0.13 \pm 0.02 \mathrm{~b}$ & $0.75 \pm 0.17 \mathrm{~b}$ & $8.76 \pm 1.44 \mathrm{~b}$ \\
$F$ value & 3.03 & 6.24 & 21.59 & 20.13 & $<0.001$ \\
$P$ value & 0.05 & 0.004 & $<0.001$ & $<0.001$ \\
\hline
\end{tabular}

sulphur-flower buckwheat. Cheatgrass reduced shoot RGR of all forbs by an average of $60 \%$, ranging from $45 \%$ for Munro's globemallow to $81 \%$ for royal penstemon.

\section{DISCUSSION}

Re-establishing native plants to restore ecosystem function, structure, and diversity following disturbance is a high priority in the Great Basin. In particular, it is of critical importance to establish plant communities that will be resistant to weed invasions and resilient to future disturbances. Because the relative growth rates of sulphur-flower buckwheat and hoary aster were not reduced when they were grown with a native grass neighbor, our results challenge previous suggestions that forbs should be seeded separately from grasses, or that forb seeding densities should be reduced to increase forb recruitment (Kindscher and Fraser 2000; Elstein 2004; Dickson and Busby 2009). These two forb species may grow well when seeded with native grasses. In contrast, the decline in RGR of royal penstemon when grown with either native grass and of Munro's globemallow when grown with bottlebrush squirreltail is consistent with other research demonstrating the potential for native grasses to reduce the establishment of specific native forbs (Brown and Bugg 2001; Dickson and Busby 2009; McCain et al. 2010).

Although only qualitatively observed, differences in root morphology may partially explain why native grasses did not reduce RGR of two of the forbs. Both sulphur-flower buckwheat and hoary aster had a columnar and vertically oriented root morphology, and both exhibited no reduction in total RGR when grown with either native grass. The root morphologies of royal penstemon and Munro's globemallow were densely fibrous, with high lateral branching, increasing spatial overlap with grasses, which shared this root morphology. Designing seed mixes to increase heterogeneity of root characteristics could result in increased species richness, and planting forbs with a columnar, vertically oriented root morphology with native grasses may be a tool to reduce niche overlap and increase species and life-form diversity (Stubbs and Wilson 2004).

Differences in forb growth patterns and response to nativegrass neighbors implies that considering all forb species as a single functional group ignores important variation in both morphology and growth rate that could be used to design diverse native seedings. For example, increasing the density of all forb species in a seed mix without an adequate understanding of this could potentially increase interspecific competition among forbs and reduce forb diversity, considering the large differences in forb biomass in the first 12 wk of growth. Likewise, reducing grass seeding rates without considering the identity and characteristics of the forb species included in the mixture could preclude an opportunity to increase invasion resistance.

Because cheatgrass densities can be high enough to preclude natural recovery of native plants (Knapp 1996), identifying

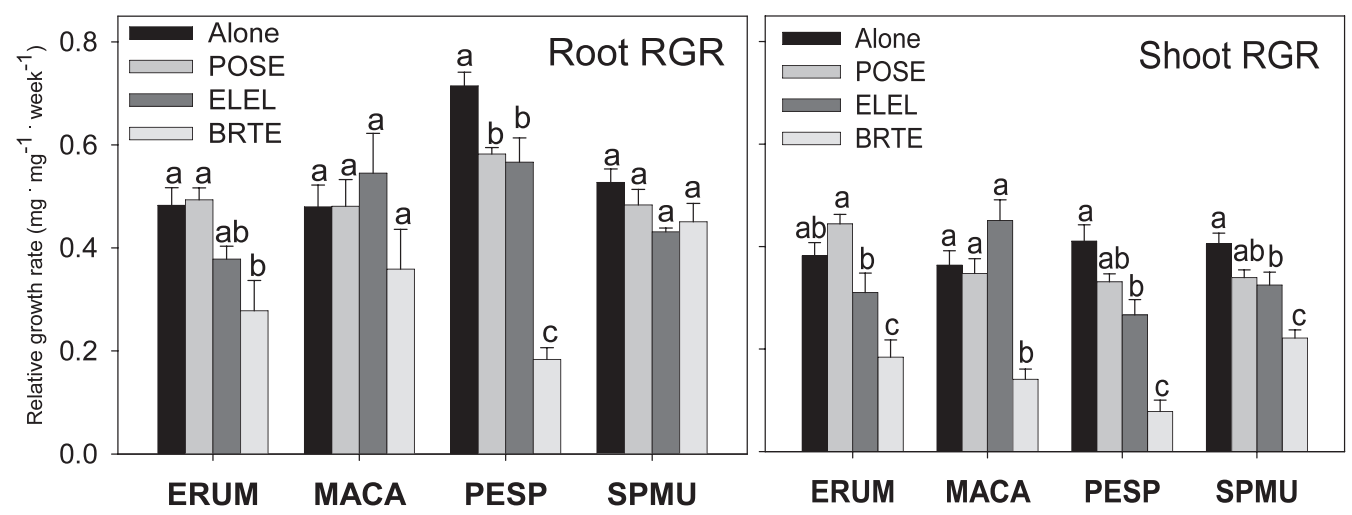

Figure 3. Forb root and shoot RGR (mg $\cdot \mathrm{mg}^{-1} \cdot \mathrm{wk}^{-1} \pm 1 \mathrm{SE}$ ) among neighbor treatments (alone or with POSE [Sandberg bluegrass], ELEL [bottlebrush squirreltail], or BRTE [cheatgrass]). Different letters indicate significant differences within forb species based on Tukey multiple-comparison tests $(P<0.05)$. Forbs: ERUM = sulphur-flower buckwheat; MACA = hoary aster; PESP=royal penstemon; SPMU=Munro's globemallow. 
how forb species vary in their competitive response to cheatgrass is important. The smallest forb in this study, bigseed biscuitroot, and the largest, Munro's globemallow, exhibited the least reduction in biomass when grown with cheatgrass $(51 \%$ and $64 \%)$, illustrating that biomass alone is a poor indicator of ability to grow in the presence of cheatgrass. Identifying forbs that can establish and grow with cheatgrass could help design specific seed mixes to increase plant community resistance to cheatgrass invasion. In doing so, native forb species mixes should account for species differences in phenology to accommodate the life-history traits of cheatgrass. For example, as a facultative winter annual, cheatgrass may germinate in the fall, continue root growth throughout the winter, and initiate shoot growth earlier in spring than native plants, meaning it reduces soil water content and has a large size advantage over spring-emerging forb seedlings (Arredondo et al. 1998). Consequently, it is feasible that species that germinate early, such as bigseed biscuitroot and other species of biscuitroot grown for restoration (i.e., fernleaf biscuitroot $[L$. dissectum], nineleaf biscuitroot $[L$. triternatum], and Gray's biscuitroot [L. grayi]) (Scholten et al. 2009), will be less impacted by cheatgrass in early spring than species that germinate in mid-spring, approximately the time frame when cheatgrass begins to cause detectable differences in soil water content (Parkinson 2008).

The high cost of native seed and the decreasing likelihood of success with increasing cheatgrass densities are factors to be considered when designing a revegetation project. Although we cannot recommend that any of these species be seeded in areas expected to have high cheatgrass densities, our data suggest that species such as royal penstemon only be selected when the risk of cheatgrass invasion is anticipated to be very low. Because the presence of native grasses may reduce cheatgrass invasion, the inclusion of forb species that grow well with native grasses can enhance partitioning of resources, increase species richness of the established community (Pyke and Archer 1991; Schwinning and Ehleringer 2001), and potentially reduce invasion of exotic species.

\section{IMPLICATIONS}

The low survival and establishment that characterize many restoration seedings in arid environments like the Great Basin may be improved by defining variability among candidate restoration forb species for specific morphological and growth rate differences as well as competitive responses to cheatgrass. Previous research recommends that forbs be seeded separately from grasses to increase forb recruitment. Our research shows that such a broad generalization is not appropriate, as variation among forbs for relative growth rate and root morphology warrants independent consideration of species based on these characteristics. For example, forbs with densely fibrous root systems similar to those of grasses (e.g., Munro's globemallow and royal penstemon) encountered more interspecific competition from native grasses, potentially because of increased spatial overlap in the soil profile. Separating them spatially from native grasses, or seeding grasses at a reduced rate, may increase their survival. In contrast, the forbs with a tap root, or with roots oriented mainly vertically (i.e., bigseed biscuitroot [and other Lomatium spp.], hoary aster, and sulphur-flower buckwheat) may experience fewer restrictions when seeded with native grasses. Recognizing differences in root morphology, phenology, growth rates, and size will also allow managers to design species mixtures to reduce interspecific competition among seeded species. Although root growth patterns will vary in the field based on resource levels and interactions with other species, differences in root morphology may be used in future studies to investigate the potential for resource partitioning (Ray-Mukherjee et al. 2011). Combining the information on root morphology with observations on relative emergence dates and periods of primary growth among forbs and native grasses will likely increase our ability to select seeding strategies that minimize negative interactions among seeded species, while allowing for the development of plant communities more resistant to invasion by cheatgrass.

\section{ACKNOWLEDGMENTS}

Many thanks go to staff at the USDA Forest Service, Rocky Mountain Research Station in Boise, ID, including Matt Fisk, Jan Gurr, Danielle Scholten, Melissa Scholten and Nick Williams, who collected and cleaned seed and assisted with stratification protocols. Additional thanks to anonymous reviewers who provided helpful critique of the manuscript.

\section{LITERATURE CITED}

AguirRe, L., AND D. A. Johnson. 1991. Influence of temperature and cheatgrass competition on seedling development of two bunchgrasses. Journal of Range Management 44:347-354.

Arredondo, J. T., T. A. Jones, and D. A. Johnson. 1998. Seedling growth of Intermountain perennial and weedy annual grasses. Journal of Range Management 51:584-589.

Beale, D. M., and A. D. Smith. 1970. Forage use, water consumption and productivity of pronghorn antelope in western Utah. The Journal of Wildlife Management 34:570-582.

Beckstead, J., and C. K. Augspurger. 2004. An experimental test of resistance to cheatgrass invasion: limiting resources at different life stages. Biological Invasions 6:417-432.

Booth, M. S., M. M. Caldwell, and J. M. Stark. 2003. Overlapping resource use in three Great Basin species: implications for community invasibility and vegetation dynamics. Journal of Ecology 91:36-48.

Brown, C. S., AND R. L. Bugg. 2001. Effects of established perennial grasses on introduction of native forbs in California. Restoration Ecology 9:38-48.

Chambers, J. C., B. A. Roundy, R. R. Blank, S. E. Meyer, and A. Whittaker. 2007. What makes Great Basin sagebrush ecosystems invasible by Bromus tectorum? Ecological Monographs 77:117-145.

Cline, J. F., D. W. Uresk, And W. H. Rickard. 1977. Comparison of soil-water used by a sagebrush-bunchgrass and a cheatgrass community. Journal of Range Management 30:199-201.

Davies, K. W., and J. D. Bates. 2010. Native perennial forb variation between mountain big sagebrush and Wyoming big sagebrush plant communities. Environmental Management 46:452-458.

DePuit, E. J. 1986. The role of crested wheatgrass in reclamation of drastically disturbed lands. In: K. L. Johnson [ED.]. Crested wheatgrass: its values, problems and myths. Symposium Proceedings. Logan, UT, USA: Utah State University. p. $323-330$.

Dickson, T. L., And W. H. Busby. 2009. Forb species establishment increases with decreased grass seeding density and with increased forb seeding density in a northeast Kansas U.S.A. experimental prairie restoration. Restoration Ecology 17:597-605. 
Drut, M. S., W. H. Pyle, and J. A. Crawford. 1994. Technical note-diets and food selection of sage grouse chicks in Oregon. Journal of Range Management 47:90-93.

Elsteln, D. 2004. A friendly solution to restoration. Agricultural Research Magazine $52: 20-21$.

Gathmann, A., and T. Tscharntke. 2002. Foraging ranges of solitary bees. Journal of Animal Ecology 71:757-764.

Getz, H. L., AND W. L. BAKer. 2008. Initial invasion of cheatgrass (Bromus tectorum) into burned pinyon-juniper woodlands in western Colorado. American Midland Naturalist 159:489-497.

GoldberG, D. E., and K. Landa. 1991. Competitive effect and response-hierarchies and correlated traits in the early stages of competition. Journal of Ecology 79:1013-1030.

Gregg, M. A., J. K. Barnett, and J. A. Crawford. 2008. Temporal variation in diet and nutrition of preincubating greater sage-grouse. Rangeland Ecology \& Management 61:535-542.

Humphrey, L. D., AND E. W. Schupp. 2004. Competition as a barrier to establishment of a native perennial grass (Elymus elymoides) in alien annual grass (Bromus tectorum) communities. Journal of Arid Environments 58:405-422.

James, J. J., K. W. Davies, R. L. Sheley, and Z. T. Aanderud. 2008. Linking nitrogen partitioning and species abundance to invasion resistance in the Great Basin. Oecologia 156:637-648.

Kindscher, K., and A. Fraser. 2000. Planting forbs first provides greater species diversity in tallgrass prairie restorations. Ecological Restoration 18:115-116.

Knapp, P. A. 1996. Cheatgrass (Bromus tectorum L) dominance in the Great Basin Desert-history, persistence, and influences to human activities. Global Environmental Change_-Human and Policy Dimensions 6:37-52.

KufeLd, R. C. 1973. Foods eaten by the Rocky Mountain elk. Journal of Rangeland Management 26:106-113.

LEgER, E. A. 2008. The adaptive value of remnant native plants in invaded communities: an example from the Great Basin. Ecological Applications 18:1226-1235.

Mack, R. N., AND D. A. PYKE. 1983. The demography of Bromus tectorum-variation in time and space. Journal of Ecology 71:69-93.

McCain, K., G. Wilson, And J. BlaiR. 2010. Mycorrhizal suppression alters plant productivity and forb establishment in a grass-dominated prairie restoration. Plant Ecology 212:1675-1685.

Parkinson, H. 2008. Impacts of native grasses and cheatgrass on Great Basin forb development [thesis]. Bozeman, MT, USA: Montana State University. 75 p.
Plummer, A., D. Christensen, and S. Monsen. 1968. Restoring big game range in Utah. Vol. 68-3. Salt Lake City, UT, USA: Utah Division of Fish and Game. 183 p.

PooRTer, H. 1989. Plant growth analysis: towards a synthesis of the classical and the functional approach. Physiologia Plantarum 75:237-244.

PooRter, H., AND C. LewIs. 1986. Testing differences in relative growth rates: a method avoiding curve fitting and pairing. Physiologia Plantarum 67:223-226.

PYKE, D. A., AND S. ARCHER. 1991. Plant-plant interactions affecting plant establishment and persistence on revegetated rangeland. Journal of Range Management 44:550-557.

Ray-Mukheruee, J., T. A. Jones, P. B. Adler, and T. A. Monaco. 2011. Immature seedling growth of two North American native perennial bunchgrasses and the invasive grass Bromus tectorum. Rangeland Ecology \& Management 64:358-365.

Scholten, M., J. Donahue, N. L. Shaw, and M. D. Serpe. 2009. Environmental regulation of dormancy loss in seeds of Lomatium dissectum (Apiaceae). Annals of Botany 103:1091-1101.

Schwinning, S., and J. R. Ehleringer. 2001. Water use trade-offs and optimal adaptations to pulse-driven arid ecosystems. Journal of Ecology 89:464-480.

Shaw, N. L., S. M. Lambert, A. M. DeBolt, and M. Pellant. 2005. Increasing native forb seed supplies for the Great Basin. In: L. Riley and R. K. Dumroese [TECH. COORDS.]. National Proceedings: Forest and Conservation Nursery Associations-2004; 12-15 July 2004; Charleston, NC, USA; and 26-29 July 2004; Medford, OR, USA. Fort Collins, C0, USA: USDA Forest Service. RMRS-P-35. p. 94-102.

SPSS. 2006. SPSS for Windows, Rel. 15.0.1. Chicago, IL, USA: SPSS Inc.

StuBBS, W. J., AND J. B. WILSON. 2004. Evidence for limiting similarity in a sand dune community. Journal of Ecology 92:557-567.

WalkeR, S. C., AND N. L. Shaw. 2005. Current and potential use of broadleaf herbs for re-establishing native communities. In: N. L. Shaw, S. B. Monsen, and M. Pellant [comPs.]. Sage-grouse Habitat Improvement Symposium; 4-7 June 2001; Boise, ID, USA. Ogden, UT, USA: USDA Forest Service Rocky Mountain Research Station. Proceedings RMRS-P-38. p. 56-61.

YelenIK, S. G., And S. M. Levine. 2010. Processes limiting native shrub recovery in exotic grasslands after non-native herbivore removal. Restoration Ecology 18:418-425.

Young, J. A., And R. A. Evans. 1978. Population dynamics after wildfires in sagebrush grasslands. Journal of Range Management 31:283-289.

Young, J. A., R. A. Evans, and R. Weaver. 1976. Estimating potential downy brome competition after wildfire. Journal of Range Management 29:322-325. 